\author{
Nina Siemieniuk \\ Uniwersytet w Bialymstoku \\ Tomasz Siemieniuk \\ Wyższa Szkoła Finansów i Zarzq̨dzania w Bialymstoku \\ Lukasz Siemieniuk \\ Uniwersytet w Bialymstoku
}

\title{
Wybrane aspekty wykorzystania teorii chaosu do wspierania decyzji finansowych
}

\section{SELECTED ASPECTS OF THE USE OF CHAOS THEORY TO SUPPORT FINANCIAL DECISIONS}

\begin{abstract}
Celem publikacji jest omówienie wybranych aspektów teorii chaosu deterministycznego, oraz prezentacja rezultatów badań dotyczqcych możliwości wykorzystania narzędzi chaosu deterministycznego (wymiaru fraktalnego, wyktadnika Hursta) do wspierania decyzji finansowych inwestorów giełdowych na przykładzie wybranych spółek funkcjonujacych na Giełdzie Papierów Wartościowych w Warszawie.

Decyzje finansowe dotyczqce inwestowania na rynku kapitałowym sa na calym świecie przedmiotem licznych badań $i$ analiz. Wykorzystuje się $w$ nich różne metody $i$ narzędzia badawcze. W celu prognozowania decyzji finansowych konstruowane sq rozmaite modele, które nigdy nie daja petnej pewności sukcesu i sq obarczone, zwykle ryzykiem inwestycyjnym. Jednq z nowszych koncepcji wspomagania decyzji finansowych jest teoria chaosu deterministycznego. Cechy charakterystyczne, stany nierównowagi oraz mechanizm sprzężenia zwrotnego $w$ wymiarze czasowym, znajduja swój wyraz w opisie za pomoca dynamicznych systemów nieliniowych.
\end{abstract}

Słowa kluczowe: teoria chaosu, rynki kapitałowe, analiza R/S, wykładnik Hursta, wymiar fraktalny

\section{Wprowadzenie}

Decyzje finansowe dotyczące inwestowania na rynku kapitałowym są na całym świecie przedmiotem licznych badań i analiz. Wykorzystuje się w nich różne metody i narzędzia badawcze. Próby opisu powyższych decyzji podejmowane są w ramach wielu dyscyplin naukowych, np. ekonomii, matematyki, psychologii. Rozmaitość stosowanych teorii i metod znajduje swój wyraz w różnorodności uzyskiwanych wyników i prognoz. Osiagnięcie sukcesu przy podejmowaniu decyzji finansowych jest bardzo trudne, ponieważ proces podejmowania decyzji jest dynamiczny i prawie nigdy nie znajduje się $\mathrm{w}$ równowadze. Strategie działania $\mathrm{w}$ tym zakresie są, $\mathrm{z}$ metodologicznego punktu widzenia, najtrudniejsze ze zbioru wszystkich strategii stosowanych w gospodarce. W celu wspomagania decyzji finansowych konstruowane są rozmaite modele, które nigdy nie dają pełnej pewności sukcesu i są obarczone, zwykle ryzykiem inwestycyjnym. 
Jedną z nowszych koncepcji wspomagania decyzji finansowych jest teoria chaosu deterministycznego. Cechy charakterystyczne, stany nierównowagi oraz mechanizm sprzężenia zwrotnego w wymiarze czasowym, znajdują swój wyraz w opisie za pomocą dynamicznych systemów nieliniowych.

Celem publikacji jest omówienie wybranych aspektów teorii chaosu deterministycznego, oraz prezentacja rezultatów badań dotyczących możliwości wykorzystania narzędzi chaosu deterministycznego (wymiaru fraktalnego, wykładnika Hursta) do wspierania decyzji finansowych inwestorów giełdowych na przykładzie wybranych spółek funkcjonujących na Giełdzie Papierów Wartościowych w Warszawie.

\section{Istota chaosu deterministycznego}

W literaturze $\mathrm{z}$ zakresu teorii chaosu istnieje wiele równoważnych definicji chaosu deterministycznego. Jednym z powodów takiej sytuacji jest to, iż teoria chaosu powstała na pograniczu kilku dyscyplin naukowych. Do najpowszechniej akceptowanych zaliczamy definicję zaproponowaną w 1986 roku przez Królewskie Towarzystwo Naukowe w Londynie, które opisało chaos jako ,przypadkowe wydarzenia pojawiające się w deterministycznym systemie."

W teorii chaosu zakłada się, że złożoność zjawisk może być przyczyną znacznie odmiennych w czasie zachowań układów (wykładniczym rozbieganiem się trajektorii w przestrzeni fazowej) o podobnych portretach fazowych na poszczególnych etapach cyklu. Zjawiska dynamiczne mogą być opisane modelami dynamicznymi, których nieregularność zależy od stopnia ich nieliniowości ${ }^{2}$.

Teoria chaosu odnosi się do nieliniowych modeli dynamiki. Rewolucję w zastosowaniu teorii chaosu w dziedzinie finansów wywołał krach na rynkach finansowych pod koniec 1987 roku. Wielu ekonomistów zaczęło poważnie myśleć o wykorzystaniu teorii dynamiki nieliniowej oraz teorii chaosu do opisu i przewidywania zachowań rynków kapitałowych ${ }^{3}$.

Istota chaosu deterministycznego tkwi we wrażliwości układu na warunki początkowe. Symbolem tej teorii jest atraktor Lorenza. Układ Lorenza przedstawia wpływ zmian wartości typowych parametrów dla nieliniowych układów na ich wrażliwość, przez co mogą wystapić skokowe, nagłe przejścia od dynamiki regularnej do chaotycznej, są to tzw. bifurkacje ${ }^{4}$.

Niemożliwe jest przewidzenie zmian dla dłuższego okresu czasowego, można ustalić warunki na początek ze skończoną dokładnością, ponieważ zmiana jednej cyfry na którymś z miejsc po przecinku, zaczynając od pewnego momentu symulacji, powoduje wzrost błędu obliczeń w sposób wykładniczy. Uzyskanie dokładnej trajektorii

\footnotetext{
${ }^{1}$ A. Gabryś: Zarzq̨dzanie wartościq spółki w kontekście teorii chaosu, Wydawnictwo Aurea Mediocritas, Warszawa 2007, s. 13.

${ }^{2}$ A. Gabryś: op. cit., s. 97.

${ }^{3}$ N. Siemieniuk, J. Kilon: Technologie informatyczne na rynku kapitałowym, Wydawnictwo Wyższej Szkoły

Finansów i Zarządzania w Białymstoku, Białystok 2006, s. 91.

${ }^{4}$ P. Fritzkowski: $O$ chaosie deterministycznym., Wydział Budowy Maszyn i Zarządzania, Wydawnictwo Politechniki Poznańskiej, Poznań 2015, s.4-5.
} 
w nieskończenie długim zasięgu czasowym wymagałoby przedstawienia nieskończenie wielu cyfr po przecinku, a to nie jest możliwe w praktyce ${ }^{5}$.

Jak podaje N. Siemieniuk, T. Siemieniuk, „Można stwierdzić, iż teoria chaosu pozwala ująć w sposób ilościowy dynamikę niepewności i odnaleźć porządek w jej nieregularnościach. Przemawia ona do wyobraźni ukazując, jak złożone zachowania mogą wyrastać z prostych deterministycznych równań. Rezultat jest chaotyczny, mimo że sam proces jest uporządkowany. Chaos i porządek wspótistnieją ze sobą. Pomimo, iż w chaosie obecny jest porządek, to $\mathrm{w}$ dłuższym okresie czasu zachowanie systemu chaotycznego jest nieprzewidywalne. Teoria chaosu ujawnia obecny $\mathrm{w}$ naturze porządek, jednocześnie ostrzegając, że należy nauczyć się funkcjonowania w świecie niepewności’”.

Narzędziem teorii chaosu, znajdującym zastosowanie w analizie szeregów finansowych, jest wykładnik Hursta i wymiar fraktalny. Wykorzystanie wykładnika Hursta bazuje na spostrzeżeniu faktu, iż liczne procesy naturalne wykazują bardzo długie cykle, a więc ich teraźniejsze obserwacje zależą od obserwacji z przeszłości. Wymiar fraktalny jest ważną informacją o systemie, ponieważ umożliwia określenie minimalnej liczby zmiennych dynamicznych, niezbędnych do opisania układu. Jednocześnie wymiar fraktalny stanowi dolną granicę liczby możliwych stopni swobody np. w podejmowaniu decyzji finansowych.

\section{Wykorzystanie wymiaru fraktalnego i wykładnika Hursta w decyzjach finansowych}

Wymiar fraktalny można zastosować do charakterystyki szeregów finansowych. Za wymiar szeregu finansowego przyjmuje się wymiar krzywej będącej wykresem rozważanego szeregu. Zdefiniowana $\mathrm{w}$ ten sposób miara określa stopień poszarpania wykresu, a zatem w sposób naturalny można przyjąć, że im większy jest wymiar szeregu, tym większa jego zmienność. Niesie to praktyczne konsekwencje dla zastosowania wymiaru fraktalnego $\mathrm{w}$ analizie ryzyka finansowego inwestorów giełdowych. Akcje, których szeregi cen mają większy wymiar, są bardziej zmienne, a co za tym idzie, bardziej ryzykowne?

Do analizy decyzji finansowych na przykładzie wybranych spółek akcyjnych z polskiej giełdy za pomoca metod chaosu deterministycznego wykorzystano wymiar fraktalny i wymiar korelacyjny (tabela 1).

Tabela 1. Wymiar fraktalny i korelacyjny dla wybranych spółek akcyjnych z polskiej giełdy.

\begin{tabular}{|c|c|c|}
\hline Nazwa spółki & Wymiar fraktalny & $\begin{array}{c}\text { Wymiar korelacyjny } \\
\text { (liczba zmiennych) }\end{array}$ \\
\hline Dębica & 4,32 & 5 \\
PKOBP & 3,01 & 4 \\
Próchnik & 8,63 & 9 \\
\hline
\end{tabular}

Źródło: opracowanie własne.

\footnotetext{
5 M.Gajer: Czy chaos deterministyczny jest chaosem? „Przeglądy-Poglądy. Wiadomości elektrotechniczne” 2004 nr 5, Wydawnictwo SIGMA-NOT, Warszawa 2004, s. 18-19.

${ }^{6}$ N. Siemieniuk, T. Siemieniuk: Teoria chaosu deterministycznego a decyzje inwestorów giełdowych, „Zeszyty Naukowe Uniwersytetu Szczecińskiego", nr 855, 2015, s. 184.

${ }^{7}$ W. Orzeszko: Wymiar fraktalny szeregów czasowych a ryzyko inwestowania, Wydawnictwo Naukowe Uniwersytetu Mikołaja Kopernika, Toruń 2010, s. 58.
} 
Z wymiarem korelacyjnym wiąże się pojęcie wymiaru fraktalnego, który charakteryzuje sposób wypełnienia przestrzeni przez dany układ i wskazuje na liczbę stopni swobody tego układu. Wymiar korelacyjny jest szacunkiem wymiaru fraktalnego, jest to najbliższa liczba całkowita, wyższa od wymiaru fraktalnego, określająca minimalną liczbę zmiennych, konieczną do sporządzenia modelu dynamiki systemu. Im liczba ta jest mniejsza, tym układ jest prostszy, im większa, tym bardziej złożony. Jeżeli liczba zmiennych przekracza 9 można mówić o tzw. multifraktalu.

Analiza ma na celu wyznaczenie wymiaru fraktalnego zrekonstruowanego atraktora dla szeregów notowań akcji wybranych spółek akcyjnych z polskiej giełdy w celu zbadania kondycji spółki z polskiej giełdy i podania informacji do podjęcia decyzji finansowych dla inwestorów giełdowych.

W tabeli 1 podano wartości wymiaru fraktalnego i wymiaru korelacyjnego dla wybranych spółek akcyjnych z polskiej giełdy. Rysunki: 1-3 przedstawiają wymiary fraktalne $\mathrm{w}$ odniesieniu do szeregów notowań akcji wybranych spółek akcyjnych $\mathrm{z}$ polskiej giełdy.

Dla szeregu zwrotów notowań akcji spółki Dębica obliczono wymiary fraktalne w odniesieniu do notowań akcji w okresie 02.01.1995-05.04.2012 dla zanurzeń 1-20 i opóźnienia czasowego $\tau=7$. Wyniki analizy prezentuje rysunek1. Wymiary korelacyjne stabilizują się od siedemnastego wymiaru zanurzenia, przyjmując wartość 4,32. Ponieważ jest to wartość niecałkowita, można stwierdzić, iż w szeregu obserwuje się zjawisko chaosu deterministycznego. Świadczy to o istnieniu pięciu niezależnych zmiennych w badanym procesie. Dane zamieszczone w tabeli 1 wyraźnie wskazują na fraktalny charakter szeregu czasowego notowań akcji spółki Dębica. Wymiar fraktalny równy 4,32 oznacza, że możliwe jest modelowanie tego rynku za pomocą pięciu zmiennych.

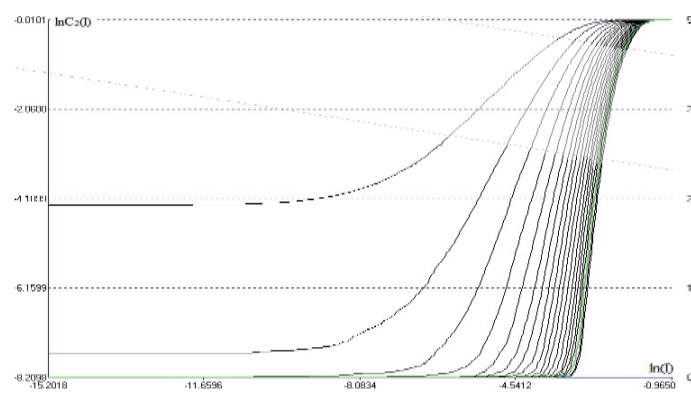

a)

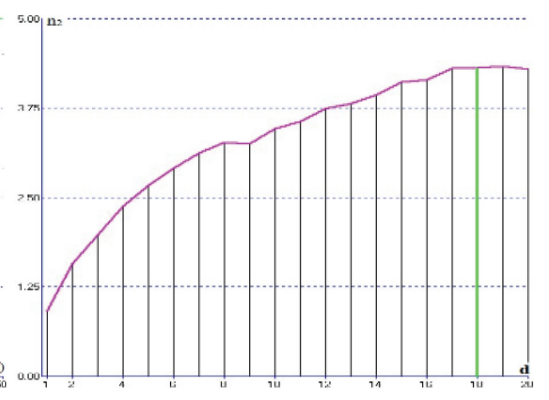

b)

Rysunek 1. Określenie wymiaru fraktalnego na podstawie wymiarów korelacyjnych dla notowań akcji Dębica w okresie 02.01.1995- 05.04.2012 $\tau=7$ : a) krzywe $\operatorname{lnC}(1)$, b) wymiary korelacyjne dla zanurzeń 1-20 obliczone na podstawie nachyleń prostych regresji stycznych do krzywych z oznaczonego obrazu.

Źródło: opracowanie własne.

Dla szeregu zwrotów notowań akcji spółki PKOBP, obliczono wymiary fraktalne w odniesieniu do notowań akcji w okresie 10.11.2004-05.04.2012 dla zanurzeń 1-20 i opóźnienia czasowego $\tau=7$. Wyniki analizy prezentuje rysunek 2 . Wymiary korelacyjne stabilizują się od osiemnastego wymiaru zanurzenia, przyjmując wartość 3,01 . Ponieważ 
jest to wartość niecałkowita, można stwierdzić, iż w szeregu obserwuje się zjawisko chaosu deterministycznego. Świadczy to o istnieniu czterech niezależnych zmiennych w badanym procesie. Dane zamieszczone w tabeli 1 wyraźnie wskazują na fraktalny charakter szeregu czasowego notowań akcji spółki PKOBP. Wymiar fraktalny równy 3,01 oznacza, że możliwe jest modelowanie tego rynku za pomocą czterech zmiennych.

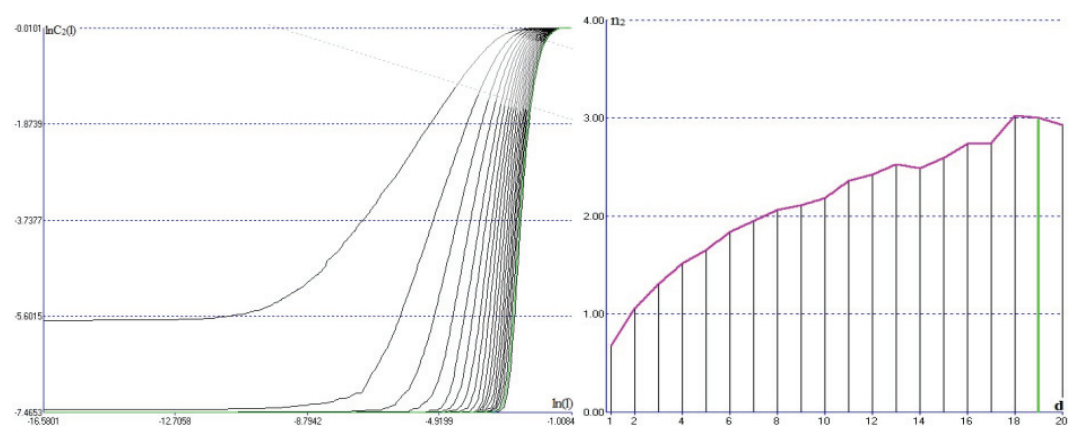

a)

b)

Rysunek 2. Określenie wymiaru fraktalnego na podstawie wymiarów korelacyjnych dla notowań akcji PKOBP w okresie 10.11.2004- 05.04.2012 $\tau=7$ : a) krzywe $\operatorname{lnC}(1)$, b) wymiary korelacyjne dla zanurzeń 1-20 obliczone na podstawie nachyleń prostych regresji stycznych do krzywych $\mathrm{z}$ oznaczonego obrazu

Źródło: opracowanie własne.

Dla szeregu zwrotów notowań akcji spółki Próchnik obliczono wymiary fraktalne w odniesieniu do notowań akcji w okresie 02.01.1995-05.04.2012 dla zanurzeń 1-20 i opóźnienia czasowego $\tau=7$. Wyniki analizy prezentuje rysunek 3 . Wymiary korelacyjne stabilizują się od osiemnastego wymiaru zanurzenia, przyjmując wartość 8,63. Ponieważ jest to wartość niecałkowita, można stwierdzić, iż w szeregu obserwuje się zjawisko chaosu deterministycznego. Świadczy to o istnieniu dziewięciu niezależnych zmiennych w badanym procesie. Dane zamieszczone w tabeli 1 wyraźnie wskazują na fraktalny charakter szeregu czasowego notowań akcji spółki Próchnik. Wymiar fraktalny równy 8,63 oznacza, że możliwe jest modelowanie tego rynku za pomocą dziewięciu zmiennych. 


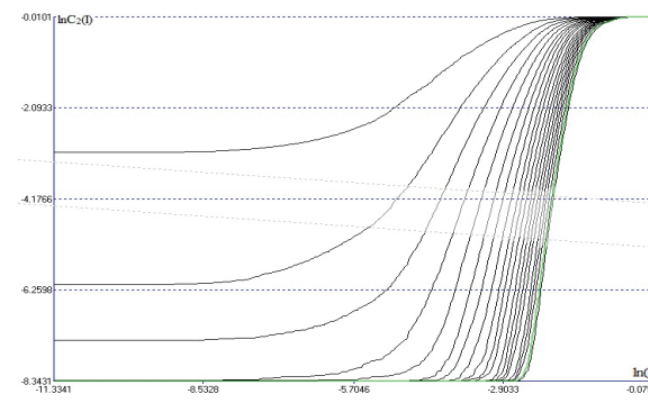

a)

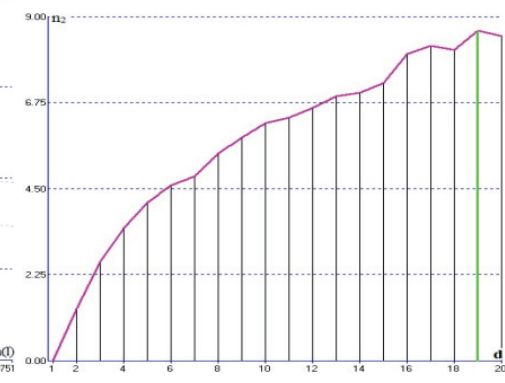

b)

Rysunek 3. Określenie wymiaru fraktalnego na podstawie wymiarów korelacyjnych dla notowań akcji Próchnik w okresie 02.01.1995- 05.04.2012 $\tau=7$ : a) krzywe $\operatorname{lnC}(1)$, b) wymiary korelacyjne dla zanurzeń 1-20 obliczone na podstawie nachyleń prostych regresji stycznych do krzywych z oznaczonego obrazu.

Źródło: opracowanie własne.

Analizując dane z tabeli 1 i rysunków 1-3 dotyczące wymiaru fraktalnego wybranych spółek z polskiej giełdy, można stwierdzić, iż spółki o dobrej kondycji ekonomicznej posiadają niższy wymiar fraktalny $\mathrm{w}$ porównaniu ze spółkami o słabszej kondycji ekonomicznej na Giełdzie Papierów Wartościowych w Warszawie. Dane powyższe stanowią podstawę do podejmowania decyzji finansowych przez inwestorów giełdowych.

Kolejną metodą $\mathrm{z}$ zakresu teorii chaosu deterministycznego wspomagającą podejmowanie decyzji finansowych, pozwalającą na odróżnienie szeregów losowych od nielosowych jest analiza przeskalowanego zakresu R/S, która stanowi jedną z metod wyznaczania opóźnienia czasowego i polega na wyznaczeniu wykładnika Hursta. Służy ona do określenia efektów długotrwałej pamięci i wykrywania ułamkowych ruchów Browna. W zależności od wielkości wykładnika Hursta można mówić lub nie o występowaniu zjawiska chaosu w badanym układzie. Rozróżnia się trzy klasy wielkości wykładnika Hursta $^{8}$ :

- $\quad \mathrm{H}=0,5-$ szereg czasowy jest losowy;

- $\quad 0<\mathrm{H}<0,5$ - szereg jest antypersystentny (powracający do średniej);

- $\quad 0,5<\mathrm{H}<1-$ szereg czasowy jest persystentny, chaotyczny (wzmacniający trend).

Jak już wspomniano, wyżej omówione charakterystyki metod chaosu deterministycznego i wykładnika Hursta można zastosować do podejmowania decyzji finansowych. Do analizy wykorzystano szeregi czasowe cen akcji następujących spółek akcyjnych funkcjonujących na Giełdzie Papierów Wartościowych w Warszawie: Dębica,

8 N. Siemieniuk: Fraktalne własności polskiego rynku kapitałowego, Wydawnictwo Uniwersytetu w Białymstoku, Białystok 2001, s. 95. 
PKOBP i Próchnik. Dla powyższych spółek wyliczono wykładnik Hurta i dokonano analizy decyzji finansowych.

W tabeli 2 zaprezentowano wartości wykładnika Hursta dla spółek akcyjnych: Dębica, PKOBP i Próchnik, notowanych na polskiej giełdzie.

Tabela 2 Wartość wykładnika Hursta dla wybranych spółek akcyjnych na polskiej giełdzie.

\begin{tabular}{|c|c|}
\hline Nazwa spółki akcyjnej & Wartość wykładnika Hursta \\
\hline Dębica & 0,821 \\
PKOBP & 0,767 \\
Próchnik & 0,560 \\
\hline
\end{tabular}

Źródło: Opracowanie własne z wykorzystaniem programu RecS!

Jak wynika $\mathrm{z}$ tabeli 2 , w wyniku przeprowadzonej analizy $\mathrm{R} / \mathrm{S}$ wybranych spółek akcyjnych, wartość wykładnika Hursta wskazuje na występowanie chaosu deterministycznego.

Kolejną kwestią jest wielkość wykładnika Hursta. Na rysunku 4 podano przykładowe zmiany zmiennej losowej, w przypadku gdy wykładnik Hursta jest równy 0,9 i 0,5 .

$$
\mathrm{H}=0,9
$$

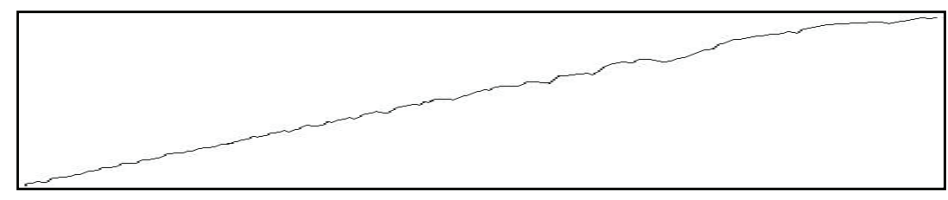

$$
\mathrm{H}=0,5
$$

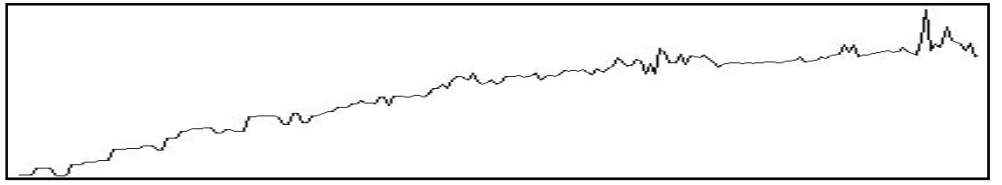

Rysunek 4. Zmiany wartości zmiennej losowej dla $\mathrm{H}=0,9$ i $\mathrm{H}=0,5$

Źródło: N. Siemieniuk, T. Siemieniuk: Teoria chaosu deterministycznego a decyzje inwestorów giełdowych, „Zeszyty Naukowe Uniwersytetu Szczecińskiego”, nr 855, 2015, s. 187.

Analizując literaturę przedmiotu można stwierdzić, iż w przypadku gdy wykładnik Hursta (H) jest mniejszy, to szereg jest bardziej chropowaty (bardziej przypadkowy). Wyższa wartość wykładnika Hursta $(\mathrm{H})$ oznacza, że podejmowanie decyzji finansowych jest obciążone niższym ryzykiem, ponieważ w takim szeregu jest mniej „,szumu”.

Powyższą zależność poddano analizie na przykładzie trzech spółek akcyjnych funkcjonujących na polskiej giełdzie: Dębica, PKOBP i Próchnik (tabela 2). Na podstawie danych z tabeli 2 można stwierdzić, iż wykładnik H dla spółki Dębica wynosi 0,821, dla spółki PKOBP jest mniejszy i wynosi 0,767 , natomiast spółkę akcyjną Próchnik charakteryzuje najniższy wykładnik H i wynosi 0,560 . Obliczeń dotyczących

\footnotetext{
${ }^{9}$ N. Siemieniuk, T. Siemieniuk: Teoria chaosu deterministycznego a decyzje inwestorów giełdowych, „Zeszyty Naukowe Uniwersytetu Szczecińskiego", nr 855, 2015, s. 187.
} 
charakterystyk chaosu deterministycznego wybranych spółek dokonano w przedziale czasowym 02.01.1995-05.04.2012 dla spółki Dębica, 10.11.2004-05.04.2012 dla spółki PKOBP, 02.01.1995-05.04.2012 dla spółki Próchnik. Na rysunku 5 zaprezentowano wykres i wielkość wykładnika Hursta dla akcji Dębica, na rysunku 7 wykres i wielkość wykładnika Hursta dla akcji PKOBP z kolei na rysunku 9 wykres i wielkość wykładnika Hursta dla akcji spółki Próchnik. Na rysunku 6 pokazano wykres notowań akcji spółki Dębica na polskiej giełdzie w latach 2013-2016, na rysunku 8 wykres notowań akcji spółki PKOBP na polskiej giełdzie w latach 2013-2016, zaś na rysunku 10 wykres notowań akcji spółki Próchnik na polskiej giełdzie w latach 1999-2016. Inwestor giełdowy po dokonaniu analizy wykładników Hursta na koniec roku 2012 mógł stwierdzić, iż najmniej ryzykowną decyzją finansową jest nabycie akcji spółki Dębica o wykładniku $\mathrm{H}$ równym 0,821 , gdyż im wyższy wykładnik Hursta tym szereg notowań akcji jest mniej chropowaty, mniej ryzykowny. W drugiej kolejności mogła być decyzja finansowa dotycząca nabycia akcji spółki PKOBP o wykładniku Hursta niższym niż w przypadku spółki Dębica i wynoszącym 0,767, najbardziej ryzykowne okazało się podjęcie decyzji finansowych dotyczących zakupu akcji Próchnik, gdzie wykładnik Hursta był najmniejszy i wyniósł 0,560, szereg notowań najbardziej chropowaty, najbardziej ryzykowny. Powyższe stwierdzenie potwierdza analiza wykresów notowań akcji Dębica, PKOBP i Próchnik (rysunki 6, 8 i 10) w roku 2013, gdzie wyraźnie widać, iż najmniej zmiennymi okazały się notowania akcji spółki Dębica o wykładniku $\mathrm{H}$ równym 0,821 , w następnej kolejności notowania cen akcji PKOBP o wykładniku $\mathrm{H}$ równym 0,767 , natomiast najbardziej ryzykowne i zmienne okazało się inwestowanie w akcje spółki Próchnik, gdzie wykładnik H był najniższy i wyniósł 0,560.

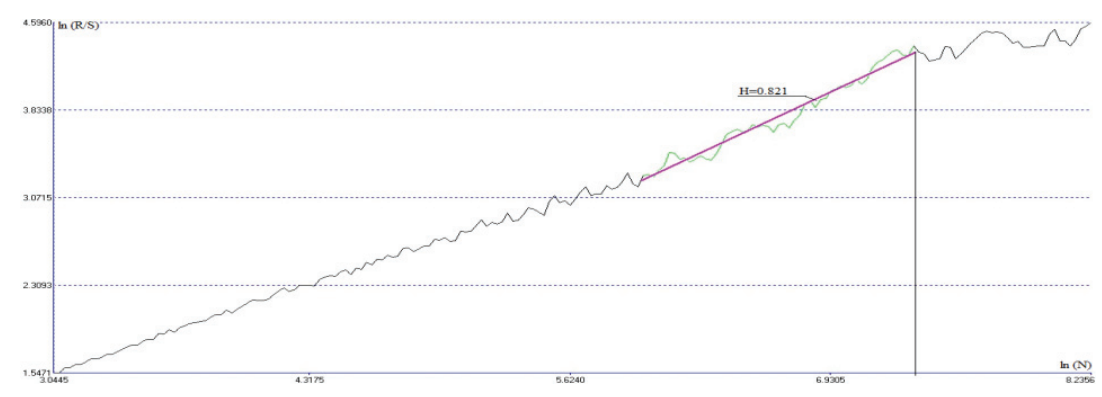

Rysunek 5. Wykładnik Hursta dla szeregu czasowego przyrostów notowań akcji Dębica w okresie 02.01.1995-05.04.2012 (dane tygodniowe).

Źródło: opracowanie własne 


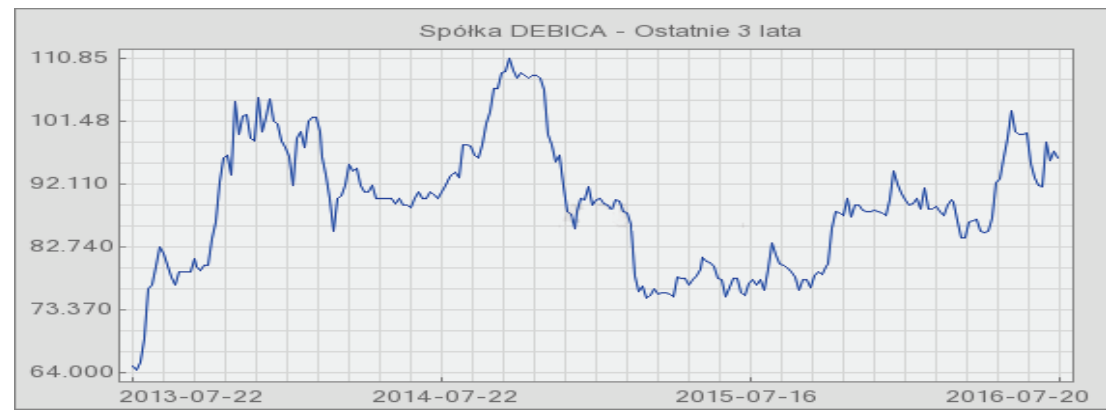

Rysunek 6. Wykres notowań akcji Dębica w latach 2013-2016.

Źródło: opracowanie na podstawie: http://mybank.pl/gielda/dbc-tc-d.html\#3lata (dostęp: 21.07.2016)

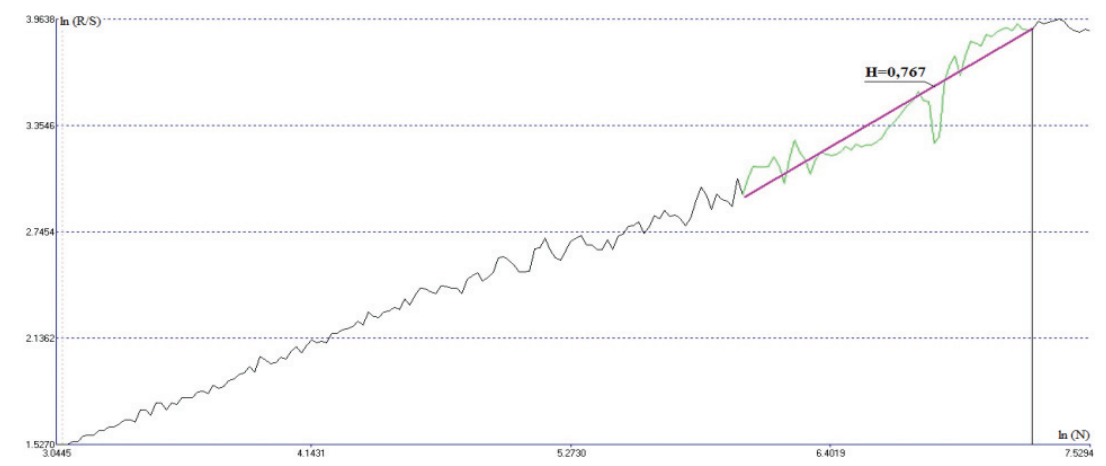

Rysunek 7. Wykładnik Hursta dla szeregu czasowego przyrostów notowań akcji PKOBP w okresie 10.11.2004-05.04.2012 (dane tygodniowe).

Źródło: opracowanie własne.

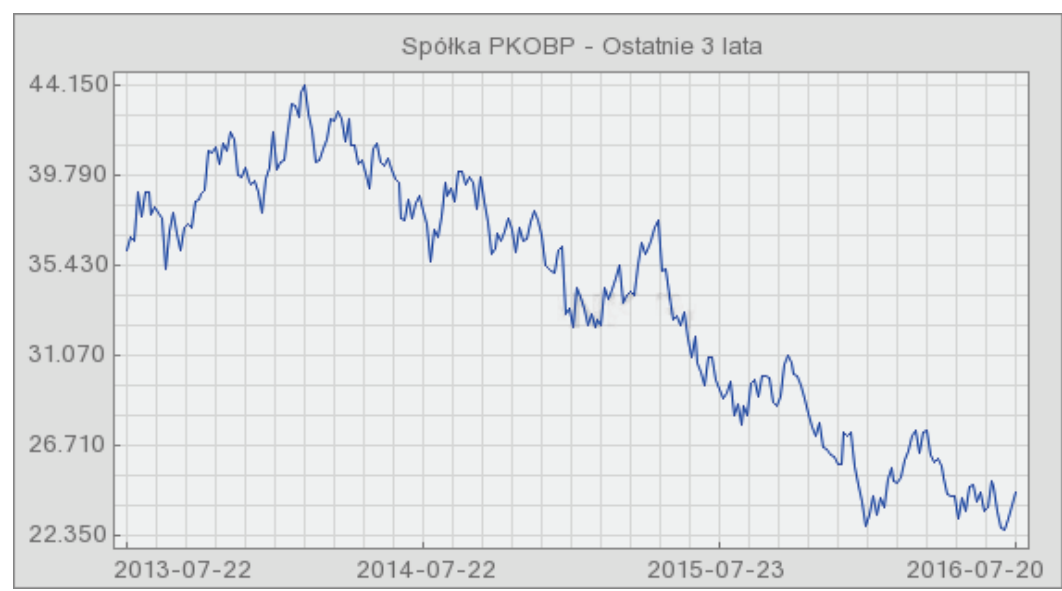

Rysunek 8. Wykres notowań akcji PKOBP w latach 2013-2016.

Źródło: opracowanie na podstawie: http://mybank.pl/gielda/pko-pko-bank-polski-sa.html\#3lata (dostęp: 21.07.2016). 


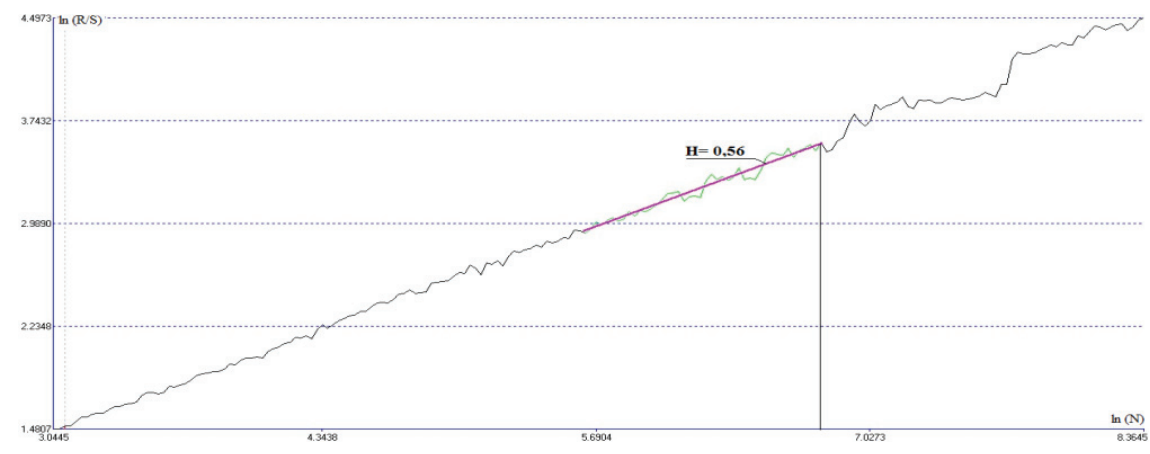

Rysunek 9. Wykładnik Hursta dla szeregu czasowego przyrostów notowań akcji Próchnik w okresie 02.01.1995-05.04.2012 (dane tygodniowe).

Źródło: opracowanie własne.

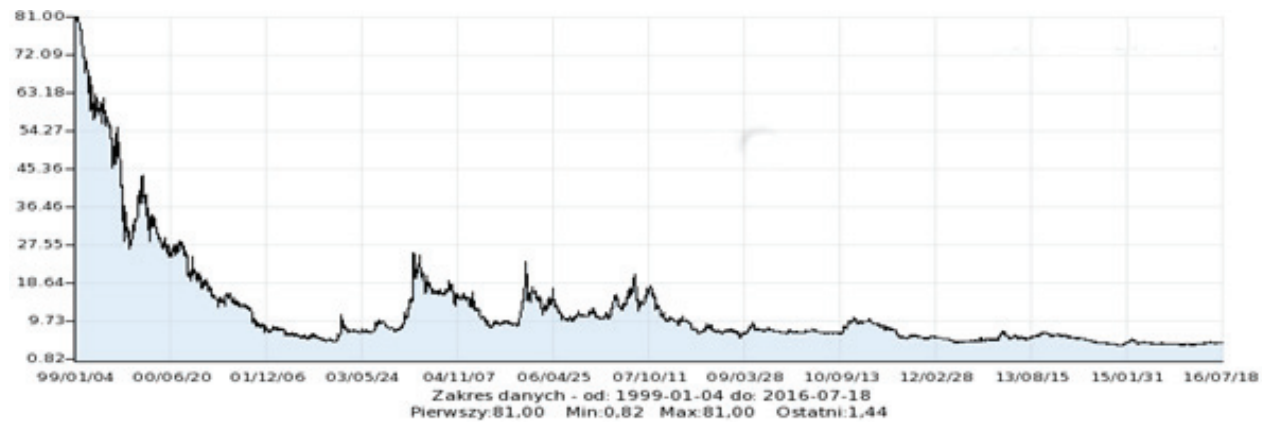

Rysunek 10. Wykres notowań akcji Próchnik w latach 1999-2016.

Źródło: opracowanie na podstawie: http://www.inwestinfo.pl/notowania-gpw/dane-spolki/prochnik208.htm?wykres=wszystko (dostęp: 18.07.2016).

\section{Podsumowanie}

Podsumowując można stwierdzić, iż w wyniku zastosowania teorii chaosu deterministycznego do wspomagania decyzji finansowych inwestorów giełdowych można wykazać strukturę fraktalną i nieliniowość takich zjawisk. Analiza fraktalna wspomagająca decyzje finansowe stanowi istotne uzupełnienie klasycznych metod analizy. Z omawianych zagadnień wynika, iż teoria chaosu deterministycznego ma znaczące zastosowanie do analizy decyzji finansowych inwestorów giełdowych. Analiza powyższa $\mathrm{z}$ powodzeniem może być wykorzystywana jest na Giełdzie Papierów Wartościowych w Warszawie. Dzięki niej można oceniać ryzyko inwestowania w konkretne akcje, a także prawdopodobieństwo występowania obliczonych prognoz.

Teoria chaosu deterministycznego wnosi istotny wkład w procesie podejmowania decyzji finansowych, gdyż bogactwo zachowań opisywanych przez nią systemów daje potencjalną możliwość wyeliminowania tej niezgodności pomiędzy teorią a praktyką. Dodatkowo systemy chaotyczne są deterministyczne, tzn. kładą nacisk na wzajemne 
oddziaływanie czynników endogenicznych, co stanowi nawiązanie do prac pierwszych badaczy cykli gospodarczych. Jeśli nawet do niektórych istniejących modeli chaotycznych można mieć z ekonomicznego punktu widzenia pewne zastrzeżenia, to jednak teoria chaosu deterministycznego $\mathrm{w}$ żaden sposób nie jest sprzeczna $\mathrm{z}$ teorią ekonomii. Z powyższych powodów lista istniejących modeli wspomagających podejmowanie decyzji finansowych wykorzystujących narzędzia chaosu deterministycznego systematycznie się powiększa, stanowiąc wyzwanie i inspirację dla badaczy.

\section{Bibliografia}

Gabryś A.: Zarzqdzanie wartościq spótki w kontekście teorii chaosu, Wydawnictwo Aurea Mediocritas, Warszawa 2007.

Fritzkowski P.: O chaosie deterministycznym., Wydział Budowy Maszyn i Zarządzania, Wydawnictwo Politechniki Poznańskiej, Poznań 2015.

Gajer M.: Czy chaos deterministyczny jest chaosem? „Przeglądy-Poglądy. Wiadomości elektrotechniczne" $2004 \mathrm{nr}$ 5, Wydawnictwo SIGMA-NOT, Warszawa 2004.

Orzeszko W.: Wymiar fraktalny szeregów czasowych a ryzyko inwestowania, Wydawnictwo Naukowe Uniwersytetu Mikołaja Kopernika, Torun 2010.

Siemieniuk N.: Fraktalne własności polskiego rynku kapitałowego, Wydawnictwo Uniwersytetu w Białymstoku, Białystok 2001.

Siemieniuk N., Kilon J.: Technologie informatyczne na rynku kapitałowym, Wydawnictwo Wyższej Szkoły Finansów i Zarządzania w Białymstoku, Białystok 2006.

Siemieniuk N., Siemieniuk T.: Teoria chaosu deterministycznego a decyzje inwestorów giełdowych, „Zeszyty Naukowe Uniwersytetu Szczecińskiego”, nr 855, 2015.

\section{Summary}

The aim of the paper is to discuss selected aspects of the deterministic chaos theory and to present the results of research on the possibility of using deterministic chaos tools (fractal dimension, Hurst exponent) to support financial decisions of stock investors on the example of selected companies operating on the Warsaw Stock Exchange.

Financial decisions on investing in the capital market are the subject of numerous studies and analyzes worldwide. Various methods and research tools are used. In order to forecast financial decisions, various models are constructed that never give full assurance of success and are burdened, usually with investment risk. One of the newer concepts of financial decision support is the theory of deterministic chaos. Characteristics, imbalances and feedback mechanisms in the time dimension find their expression in the description using dynamic non-linear systems.

Key words: chaos theory, capital markets, R/S analysis, Hurst exponent, fractal dimension

Informacja o autorach:

Dr hab. Nina Siemieniuk, prof. UwB

Uniwersytet w Białymstoku, Wydział Ekonomii i Zarządzania, Katedra Finansów Rachunkowości i Informatyki, ul. Warszawska 63, 15-062 Białystok, e-mail: n.siemieniuk@uwb.edu.pl

Mgr inż. Tomasz Siemieniuk

Wyższa Szkoła Finansów i Zarządzania w Białymstoku, Wydział Nauk Ekonomicznych, ul. Ciepła 40, 15-472 Białystok, e-mail: tomasz.siemieniuk@wsfiz.edu.pl

Dr Lukasz Siemieniuk

Uniwersytet w Białymstoku, Wydział Ekonomii i Zarządzania, Katedra Finansów Rachunkowości i Informatyki, ul. Warszawska 63, 15-062 Białystok, e-mail: 1.siemieniuk@uwb.edu.pl 